\title{
BEDENİN BİR DİRENISŞIN ESTETİĞİ OLARAK PERFORMANS SANATINA DÖNÜŞÜMÜ
}

\author{
Kıymet GÜVEN AK 1
}

\section{Özet}

Denetim ve disiplin mekanizmalarının ana öznesi olarak beden tarihsel süreç içerisinde bastırılan, disipline edilen, kapatılan bir gövde olarak sonuç verilen bir alanda olan ikametini performans sanatı aracılığıyla bir direniş öznesi olarak devam ettirmiştir. Sanatçılar bedenleri ile gerçekleştirdikleri sanatsal performanslarıyla egemen olana ve egemen olanın yönetimsel yanlışlıklarına eleştiri sunarak bedensel bir direniş estetiği yakalamışlardır. Aynı zamanda geleneksel sanat önermelerine karşı çıkan performans sanatçılarının estetik anlayışları modern estetik normlarını sarsan niteliktedir. Sanatçının kendi bedeni aynı zamanda sanatının ana malzemesidir. Bu çalışmanın amacı, bedenini sanatsal bir direnişin ve başkaldırının estetik malzemesi olarak kullanan ve direnmeye alternatif ve yaratıcı bir önerme ile yaklaşan performans sanatını ve bu sanatı gerçekleştiren performans sanatçılarını incelemektir. Çalışmada beden kavramına ve performans sanatıyla olan politik ilişkisine değinilerek sanatçı ve çalışmaları etrafından analiz edilecektir. Bedenlerinin self denetimini sanat aracılığıyla ortaya koyan sanatçıların sanat alanında ortaya koydukları yaratıcı ve alternatif yaklaşımları ortaya koyulacaktır. Bu anlamda sanatçının salt estetik kaygılarla bir üretim gerçekleştirmediği, kendi bedenini hem bir sanat malzemesi hem bir direnişin öznesi olarak cesur bir şekilde kullanarak aynı zamanda bir aktivistin dönüştürücü rolüne büründügü vurgulanmaktadır. Böylece sanatın eleştirel boyutundaki malzemenin sonsuzluğuna katkı sağlamak amaçlanmıştır.

Anahtar Kelimeler: Beden, Performans Sanatı, Vücut Sanatı, Direniş Estetiği

\section{TRANSFORMATION OF THE BODY INTO PERFORMANCE ART AS A RESISTANCE AESTHETICS}

\begin{abstract}
The body, as the main subject of control and disciplinary mechanisms, has maintained its residence in a field that has been suppressed, disciplined, and closed in the historical process as a subject of resistance through performance art. Artists have achieved an aesthetic of physical resistance by criticizing the dominant and the administrative mistakes of the dominant with their artistic performances with their bodies. At the same time, the aesthetic understanding of the
\end{abstract}

\footnotetext{
1 Öğretmen, M.E.B., ORCID NO: 0000-0002-3307-4888, temyik.2014@gmail.com
} 


\section{BEDENİN BİR DİRENISŞIN ESTETIGĞI OLARAK PERFORMANS SANATINA DÖNÜŞÜMÜ}

performance artists who oppose the traditional art proposals has the nature of shaking the modern aesthetic norms. The artist's own body is also the main material of his art. The aim of this study is to examine the performance art that uses its body as the aesthetic material of an artistic resistance and rebellion and approaches resistance with an alternative and creative proposition and the performance artists who perform this art. In the study, the concept of body and its political relationship with performance art will be addressed, and the artist and his work will be analyzed around them. The creative and alternative approaches of the artists who reveal the selfcontrol of their bodies through art will be revealed. In this sense, it is emphasized that the artist does not produce with purely aesthetic concerns, but has a transformative role like an activist by using his own body as both an art material and a subject of resistance. Thus, it is aimed to contribute to the eternity of the material in the critical dimension of art.

Keywords: Body, Performance Art, Body Art, Resistance Aesthetics

\section{Giriş}

$\mathrm{Bu}$ araştırmada, 20. yüzyılın ikinci yarısından itibaren değişen beden algısının yine aynı dönemlerle birlikte değişen sanatsal yaklaşımlarla olan devinimli ilişkisi bazı sanatçlar etrafında ele alınmıştır. Bu bağlamda bu sanatçılar, modernitenin özellikle beden üzerindeki yıkıcı felsefesi ve yaptırımlarına karşı, sanatı postmodern dönemle birlikte özgürlüğüne kavuşturarak, modern estetik ve plastik ilkelerin dişına ve ötesine geçerek, kendi bedenleri ile bir direnişin estetiğini, performans sanatı aracılığıyla görünür kılmışlardır.

Modern estetik kaygılardan ziyade toplumsal ve bireysel rahatsızlılarını kimi zaman geleneksel sanat anlayışına getirdikleri eleştiriler bağlamında, kimi zaman da ırk, cinsiyet, ötekileştirme politikaları gibi toplumda yaralar açan konulara, bir aktivist gibi yaklaşarak görünür hale getirmek istemişlerdir. Politik kaygılarını sanatsal bir dil kullanarak göstermişlerdir. Ancak kullandıkları sanat malzemeleri, tuval, fırça, boya değil kendi bedenleri ve onunla yapabilecekleri her şeydir. Bu anlamıyla sanatçılar bedenlerini bir sanat nesnesi olarak sunarak iktidar mekanizmalarının beden üzerindeki tahakkümünü eleştirmiş ve kendi bedenlerinin tahakkümünü ellerine alarak, kendi maliki olan özneye bedeni teslim etmişlerdir.

Beden modern dönem ve öncesi de dahil bütün dönemlerde şiddetin, denetimin, bastırılmanın, acının ve arzunun en fazla göründüğü yerdir. Sanatçlar, performanslarında kendi bedenleri üzerindeki denetimleri deneyimlediği ve bu deneyime izleyiciyi de katarak ortaklaştırdı̆̆ı, kimi zaman üretim sürecinin sorumluluğunu izleyiciye bıraktığı, geleneksel izleme kalıplarını kırarak, izleyiciyi aktif, sorgulayan, sorunsallaştıran rollerle buluşturan bir alanda kendi direnişlerine izleyiciyi de katan bir direnişin öznesi olarak hareket etmektedirler.

\section{Beden ve Performans}

Uluslararası Sanat ve Estetik Dergisi Yıl: 4, Sayı: 6, Haziran 2021 


\section{BEDENIN BİR DİRENIŞİN ESTETIGĞI OLARAK PERFORMANS SANATINA DÖNÜŞÜMÜ}

İnsan zihninin ikamet alanı olarak beden, insanlık tarihi boyunca hem ilahi konuların, hem sosyal konuların hem de siyasi konuların ana öznesi ve ilgi nesnesi halinde değerlendirilip irdelenmiştir. Beden üzerinde düşünce geliştiren bir çok farklı disiplin mevcuttur. Ancak uzunca zamandır akıl, ruh ve bedenin ayrı unsurlar olarak ele alınması bedenin sosyolojinin alanında değerlendirilmesini ileri tarihlere götürmüştür. "Sosyolojik gelenek içinde insanlar zihinleriyle topluma, bedenleriyle doğaya ait olarak algılandığı için, beden, tıp başta olmak üzere doğal bilimlerin, zihin ise beşeri bilimlerin nesnesi olarak ele alınmıştır" (Akçay 2004: 233). Biyolojik temellere dayandırılan bedenin toplum tarafından şekillendirildiği, sorunsallaştırıldığ 1 ve toplumunda beden tarafından, bedenler tarafından oluşturulduğu düşüncesi bedenin sosyoloji alanında görünür olduğu zamana kadar, kavramsal bağlamda gözlerden uzak kalmıştır. Özellikle felsefedeki beden ve akıl düalizminde, bedenin akla göre daha az önemli sayılması bunun sebepleri arasındadır denilebilir.

"17.yüzyıldan başlayarak, bedenin tüm anatomik ve işlevsel özellikleri genel bilimsel kurallar tarafından anlaşılabilen bir nesne olarak bilimin ona atfettiği biçimde tanımlandığ1 söylenir. Buna verilecek en önemli örnek, Descartes'tir. Descartes, 'Varım' önermesinin doğruluğunun ancak akıl tarafından algılandığında doğru olduğuna işaret eder; beden ise burada, 'tanımlanabilir' konumu, düzenlenebilir şekli olan ve uzamda yer kaplayan şey olarak tanımlanmaktadır" (Işık, 1998: s.116). Bu anlamıyla farklı uzuvların birleştiği ve bu uzuvlarla bütünleşen kütlesel bir yapı olarak düşünülebilir. "Batı düşüncesi bedeni öteki olarak kurmuştur. Bedenin bir ilgi alanı ve araştırma konusu olarak ortaya çıktığında temel sorunsal, Batı düşüncesinin Kartezyen yapısının yoğun biçimde eleştiriye açılmasıdır. Bu eleştirilerden önemli bir tanesi yapısalcılık sonrası düşünürlere aittir" (Işık, 1998: s.12). Bu düşünürlerden Foucault, Derida, Lyotard ve Baudrillard beden üzerindeki düşünceleriyle bedene ve bedenin önemine işaret edenler arasındadır. Özellikle Michel Foucault beden ile sosyolojiyi yan yana getirip, sosyolojinin gözünü bedene çekerek, bedenle de ilgilenilmesini sağlayan önemli düşünürlerdendir. O, bio-iktidar çözümlemesi üzerinden özne ve beden kavramlarıyla bir analiz yapar.

Foucault sosyolojisinde;

özneyi bedenden ve iktidardan ayırmak mümkün değildir. Çünkü Foucault'ya göre özneyle adeta varoluşsal bir ilişki içerisinde olan iktidar, bunu öznenin bedeni üzerinden de gerçekleştirmektedir. Diğer deyişle, öznenin değerlerini, söylemlerini, norm ve davranışlarını bizzat kuran, değiştirip geleceğe taşıyan iktidar, bütün bunları yaparken onun bedeninden mutlaka istifade etmektedir. Böylece bedenin kendisi de bir iktidar alanı ve göstergesi haline gelerek sosyolojik bir olguya dönüşmektedir" (Bingöl, 2019: s.327,328).

Ona göre hastaneler, okullar, askeri kışlalar ve bunlar gibi yerler iktidarın bedeni kuşatma, disipline etme gibi düşüncelerinin uygulandığı ve yayginlaştırıldı̆̆ 1 mekanlardır. 


\section{BEDENİN BİR DİRENISŞIN ESTETIGĞI OLARAK PERFORMANS SANATINA DÖNÜŞÜMÜ}

Elbette ki modern dönem öncesi, krallıklarda, monarşilerde iktidar olgusunun bedeni cezalandırma biçimleri; üstelik tiyatro sahnesine benzer şekilde; meydanlardaki gösteriler şeklinde yapılmak suretiyle de mevcuttur; ancak modernizmle ve getirdikleriyle beraber bu durumun belirtilen bu kurumlarda dahil olarak aile içerisine de girilebilecek biçimde, denetleyerek, her bir zihnin ve bedenin içine zuhur ederek bu öznelerin pasifikasyonu ile sonuçlanmıştır. Hapishanelere atılan bedenler, hastaneye konan bedenler, kışlada savaşan bedenler, okulda eğitilen bedenler iktidarın denetimi ve kontrolü altında hareket edecek şekilde programlanmaya itilir.

İktidarın ve egemen olanın yakın markajında olarak 'beden' sanatçılar içinde ayrıca bir öneme sahiptir. Özellikle 20. yüzyılda ortaya çıkan bazı sanat hareketleri beden üzerinden ve bedeni malzeme olarak kullanarak bedenin kendisiyle ilgilenmişlerdir. Bu "Performans sanatı, 'Beden Sanatı', 'Happening', 'Aksiyon' gibi çeşitli başlıklar altında gündeme gelmiş, Sitüasyonizm, Fluxus, Feminist Sanat, Arazi Sanatı gibi farklı akımlar dahilinde de uygulanmıştır" (Antmen, 2008: s. 219). Sanatçılar performanslarıyla toplumun yaşadığı politik ve sosyolojik problemleri kendisine dert edinerek sanatın yönünü oldukça yaratıcı ve güçlü bir biçimde etkilemiştir.

Beden sanat tarihinin tüm evrelerinde sayısız şekillerde tasvir edilmiş ve sanatçların repertuarında her daim güncelliğini korumuştur. Ancak performans sanatıyla birlikte, beden oldukça yaratıcı ve farklı bir medyum olarak sanatta oldukça politik bir dil ile kullanılmıştır. "Modernitenin etkisindeki erken dönem uygulamalardan günümüze performans, cinsellik eksenli, bedeni görselleştiren ve seyirlik bir durum olarak var olmaktan kurtulmuş, modernitenin üzerini örttüğü ve kimi karşıtlıklar üzerinden tanımladığı bir alan olmaktan giderek uzaklaşmıştır" (Şahiner, 2015: s.173).

Beden bir direniş malzemesi olarak sanatın dilini zenginleştiren sanatın hayatı değiştirme gücüne katkı sağlayan ve bunu sürekli bir biçimde hatırlatan, iktidar mekanizmalarının hayatı ve bedeni kuşatan uygulamalarına karşı bir direniş estetiği geliştiren en önemli bir unsur olarak kullanılmıştır performans sanatında. Postmodernizmle beraber parçalanan, modernizmin bütünsel bakış açısı; sanatın dilinin bütünlük değil farklılaştırma arayışına çevrilmesi oldukça olağandır. İzleyici bütünsel bir yapı karşısında edilgen bir biçimde izleme görevini terk ederek modernizmin kurduğu izleyici ve sanat eserindeki mesafe ortadan kaldırılmış, izleyici ve sanat üretimi arasında karşılıklı iletişim ve etkileşim üzerinden inşa edilen üretimler ortaya çıkmaktadır.

"Kaprow ve Beuys gibi sanatçılar, beden aracılı̆̆ılyla eylem anındaki varoluşa dikkat çekmişlerdi. Yves Klein, Hermann Nitsch, Marina Abramoviç Dennis Oppenheim, Bruce Nauman, Carolee Scheneemann, Chris Burden, Stelarc ve Orlan gibi sanatçlarsa araç ve nesne ilişkisini tersine çevirerek,eylem aracıllı̆ıyla beden üzerine yoğunlaştılar"(Yılmaz, 2006: s.283). 


\section{BEDENİN BİR DİRENISŞIN ESTETIGĞI OLARAK PERFORMANS SANATINA DÖNÜŞÜMÜ}

"Modernizm'in ideolojik olarak kodladığı ve toplumsalın içine yerleştirdiği beden olgusu, artık geçmişteki prosedürlerle ele alınamaz haldedir. Bedene ilişkin kodları kırılganlaştırmak, onun gerçekliğini bütüncül olarak kavrayabilmek adına artık farklı stratejilere başvurmak gerekmekte. Bu stratejilerden belki de en önemlisi sübjektif beden algısı ve bu algının dışarıda bıraktığı ötekinin varlığını da düşünmeye yol açan öznellik stratejileridir" (Şahiner, 2015: s.173-174). Bu öznellik kimi zaman bazı sanatçılar için modernliğin mesafe koyduğu ölüm gibi, çıplaklığın sınırları zorlayan görünürlüğü gibi, acı gibi, kan gibi izleyiciyle iletişimi ve etkileşimli yüzleşme düşüncelerini yeniden yapılandırma yoluna sokan stratejiler barındırır.

Schneemann, erkek egemen düşüncenin yerleştiği sanat dünyasında, kadın sanatçıların bu egemenliğin altında hareket etmelerinin önüne geçilmesine, kadınların bu dünyada ezilmelerine ve baskı altında olmalarına direnen ve bedeni aracılığıla gerçekleştirdiği üretimlerde bu durumu eleştirmeyi amaçlayan performanslar gerçekleştirmiştir. Dahili Tomar isimli performansını (Görsel 1) bu minvalde ortaya koymuştur. "Performansın başlangıcında çarşaflarla kaplı bir odaya girer. Daha sonra bu alanın ortasında soyunur ve bir masanın üzerine çıkar. Burada vücuduna çamur sürerek Schneemann vücut hatların belli eder ve resim derslerinde duran modeller gibi pozlar verir"(1). Cezanne iyi bir ressamdır isimli kendi yazdığı metni okurken sanatçı Cezanne'a bir kadın gibi hitap eder. Sanatçı bu anlamda sanat tarihindeki büyük sanatçı ve kadın sanatçı sorununa gönderme yapar.

Vajinasından çıkardığı yılankavi kağıdı Torah, göbek bağı, dil, şakül, çan kulesi ve gökkuşağına benzeten sanatçı, tarih öncesinden kalma yılan biçimli ana tanrıça simgelerinin kadınlar tarafından bedenlerine benzediği için resmedildiğini düşünür. Yılan ve vajina arasında mitolojik ilişkiler kurulur. Kutsal bilgi kaynağı ollan vajina, doğurganlığın ve arzunun gizeminin kaynağıdır. Öte yandan bu yılan biçimli kağıtta yazanlar, kadın sanatçıların erkek egemen sanat dünyasından dışlanmalarını anlatır (Özbay Aydoğan, 2006: s. 77-78). 


\section{BEDENIN BİR DİRENISŞIN ESTETIGĞI OLARAK PERFORMANS SANATINA DÖNÜŞÜMÜ}
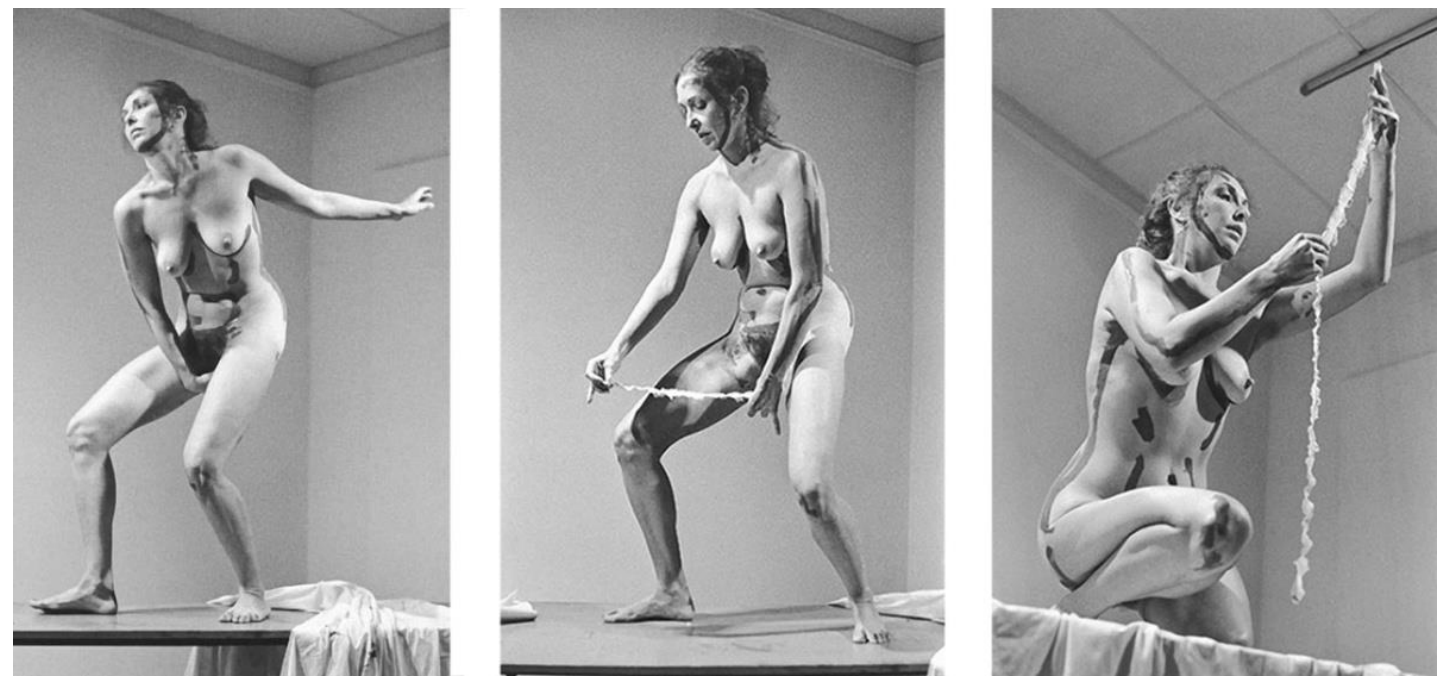

Görsel 1. Carolee Schneemann, Dahili Tomar (Interior Scroll), $1975 . \quad$ (Kaynak: https:/ / fineartmultiple.com/blog/carolee-schneemann-interior-scroll-masterpiece/)

Schneeman performanslarını çıplak şekilde gerçekleştirmektedir. Birçok feministin eleştirilerine maruz kalmasına rağmen, $\mathrm{O}$ bu şekilde erkek egemenliğini yıkmanın yolunun, direnişin çıplak kadın bedeni ile gerçekleştirilmesi ve kadın bedeninin cinsel özgürlüğe kavuşmasının etkili yolu olduğunu düşünür.

Beden ile çalışmaya 1970'li yıllarda başlayan Gina Pane performanslarını ağırlıklı olarak acıyı izleyiciyle deneyimlediği kesik, yaralanma, yanma gibi tehlikeli durumlarla gerçekleştirir. O, "bedeni psikolojik, dinsel, biyolojik ve özellikle toplumsalın oluşturduğu bir araç olarak gördüğünden, sanatın nesnesi olarak kendi bedenini kullanır. Resmin aksine bedenin derinliklerini yüzeye çıkararak akıtarak ve bedenin performatif haliyle karşılaşılması değerlidir" (Akkol, 2018: s. 1231). Beyaz giyinerek gerçekleştirdiği performanslarında, ustura, jilet gibi kesici aletlerle kolunu, yüzünü, dudaklarını keser, bu aletleri kendisine saplar, kusana kadar çürük et yer ve tüm bunları yaparken vücudundan damlayan kanın, beyaz giysisiyle bir zıtlık oluşturmasına izin vererek acının estetiğini gerçekleştirir.

1973 yılında, Milano'da gerçekleştirdiği Duygusal Eylem isimli performansında (Görsel 2) yalnızca kadın izleyicilere yer vermiştir; İki kez tekrarlayarak yaptığ1 performansın birincisinde kırmızı güller ikincisinde beyaz güller vardır. ilk aşama beyaz kıyafetli ellerinde kırmızı gül ile ilerleyip sanatçının embriyo pozisyonuyla oturmasıyla biter. Sonraki aşamada güllerin dikenlerini kolunun önyüzüne tek tek batırır ve çıkarır. Akan kan beyaz gülleri kırmızıya çevirmiştir. Performans sona erdirirken avucunu jiletle keser. Bu esnada iki kadının sesi duyulur.

Biri İtalyan ve diğeri Fransız olan sesler kadının kendi kimliğine göndermede bulunur. Kadınlar ellerinde romantik bir ilişkiyi gösteren mektuplar okurlar. Bu mektuplarda ayrıca 


\section{BEDENIN BİR DİRENISŞIN ESTETIGĞI OLARAK PERFORMANS SANATINA DÖNÜŞÜMÜ}

kadınlardan birisinin annesinin ölümünü anlatır. Bu performans, anne-çocuk ilişkisinin bir içsel yansıması olarak tanımlanmakla birlikte hem kadın hem anne hem de eşcinsel olmakla marjinalleşmenin psikolojik acısının iletilmesidir de (Akkol, 2018: s.1232).

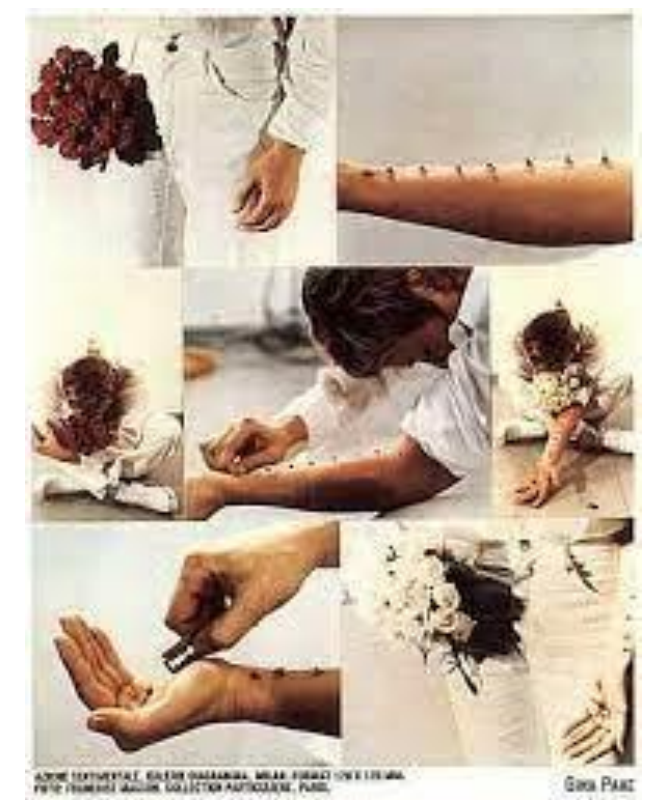

Görsel 2. Gina Pane, SentimentalAction, (DuygusalEylem1973) (Kaynak: https://www.artsy.net/artist/gina-pane )

Küba asıllı sanatçı Ana Mendieta'da aidiyet, kimlik, cinsiyet, kadın olmak gibi konuları kendi bedenini özne olarak kullandığı performanslarıyla sorgular. Onun performanslarında, özellikle doğa içerisinde gerçekleştirdiklerinde ince bir direniş estetiği görmek mümkündür diyebiliriz.

1973 yılında gerçekleştirdiği Rape Scene performansında (Görsel 3) mekan olarak kendi dairesini kullanır. Davet ettiği izleyiciler gelmeden mekanı ve bedenini oluşturduğu senaryo etrafında hazırlamıştır. İzleyiciler geldiğinde her yeri dağılmış, kan lekelerinin olduğu evde şok olacakları bir manzarayla karşılaşacaklardır. Sanatçı mutfak masasına yüz üstü bağlanmış, pantolonu ayağına kadar sıyrılmış, vücudu kanlı bir biçimde ve tecavüze uğramış bir kurban tasviriyle izleyiciyi beklemektedir. Şiddet ve kadın olgularını bu performansında net bir biçimde ortaya koyarak bedeni bir enstalasyon nesnesi olarak kullanir.

"Sanatçı, bedeni, kimi çalışmalarında kadın olmanın kendisini sorgulamış ve ürkünç, dişlanan ve şiddet uygulanan bedenleri veya cinsiyeti parodi olarak yeniden canlandırmıştır" (Özbay Aydoğan, 2006: s.68). Oldukça gerçekçi ve iyi düşünülmüş bu paradi karşısında izleyicinin şok halini tahmin etmek zor değildir. Çünkü tarih boyunca kadınlar benzer görüntüleri her coğrafyada ve kültürde yaşamış ve yaşamaktadırlar. Bu açıdan bakıldığında performans sanatının politik bir tavrı olduğu daha net 


\section{BEDENİN BİR DİRENISŞIN ESTETIGĞI OLARAK PERFORMANS SANATINA \\ DÖNÜŞÜMÜ}

anlaşılmaktadır. Kadın tecavüzleri, kadın cinayetleri ve kadına karşı işlenen adi suçlara karşı uygulanan yaptırımlara, bu suçların hala devam etmesinin ve işleyemeye niyet gösterenler açısından bakıldığında yeterince caydırıcı olmadığını görmekteyiz.

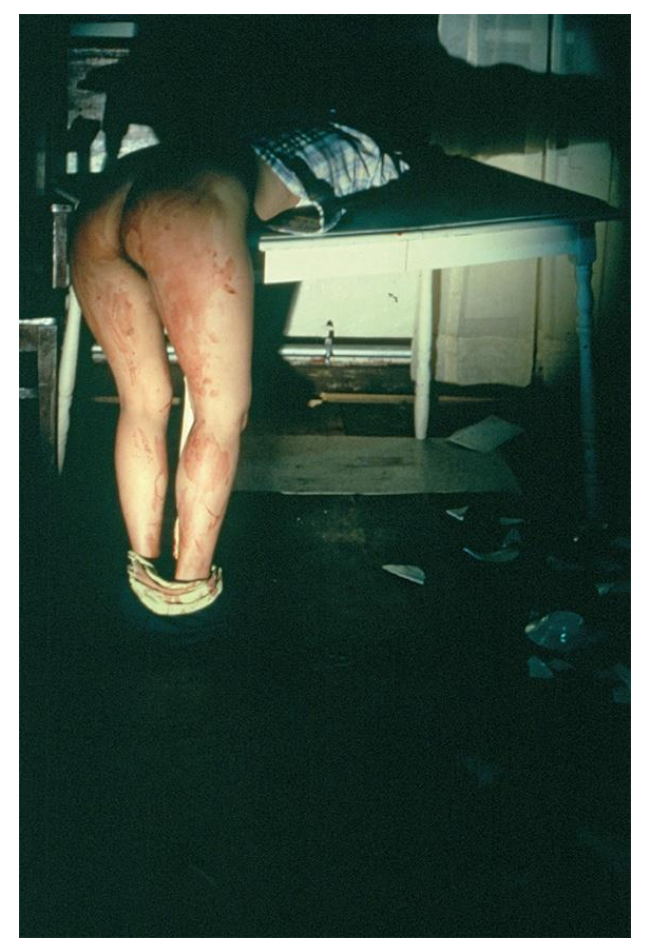

Görsel 3. Ana Mendieta, Rape Scene (1973). (Kaynak: https://www.artforum.com/print/201801/fullyloaded-power-and-sexual-violence-73188)

Başsız Kadın veya Göbek Dansı ismindeki video performans çalışmasıyla (Görsel 4) Nil Yalter, feminist direnişlerini kendi bedeni üzerinden görünür kılmıştır. Sanatçı performansına René Nelli'nin 'Erotique et Civilisations' isimli kitabındaki bir metni, siyah keçeli kalemle, göbek deliğinin etrafından başlayarak yazmasıyla başlar.

Tezkan (2009), bu metnin Afrika'nın bazı bölgelerinde yaygın olan kadın sünnetine dair etnografik bir analiz olduğunu, Anadolu'da kadın doğurganlığını artırmak için bedenine tılsımlı yazılar yazılmış kadının durumuna gönderme yaptığını belirtmektedir. Geleneğin baskısı altındaki kadının durumuna eleştirel bir ironi getirilmiştir. Kamera açısı sabit bir şekilde göbek deliğini objektifin merkezine alır. Sanatçı göbeğine metni yazar, yazıyla kaplı bir şekilde göbek dansı yapar. Video, Anadolu kadınını geleneksel yaşamın baskısıyla sıkıştırıp doğal zevklerden men edilmesine isyan eder niteliktedir. İronik bir dille eleştirirken izleyiciyi trajikomik bir olayı ayini davet eder.

Yalter bu ve diğer işleriyle dünya üzerindeki madun halklara özellikle kadınların da içinde bulunduğu ötekileştirmeye maruz kalan kesimlerin dertlerini kendisine dert edinip sanatı aracılığıyla ortaya koyduğu direnişiyle varlık mücadelesi ortaya koyar. Bu 


\section{BEDENIN BİR DİRENISŞIN ESTETIGĞI OLARAK PERFORMANS SANATINA DÖNÜŞÜMÜ}

sanatçılar içinde bulundukları ya da bulunmadıkları toplumun politik marazlarına, yaşadıkları ırkçı cinsiyetçi ya da sınıfsal ayrımcılığa karşı sanatlarını bir direniş estetiği olarak, bedenlerinde performansa dönüştürüp, avazı çıktığı kadar bağırmaktadır.

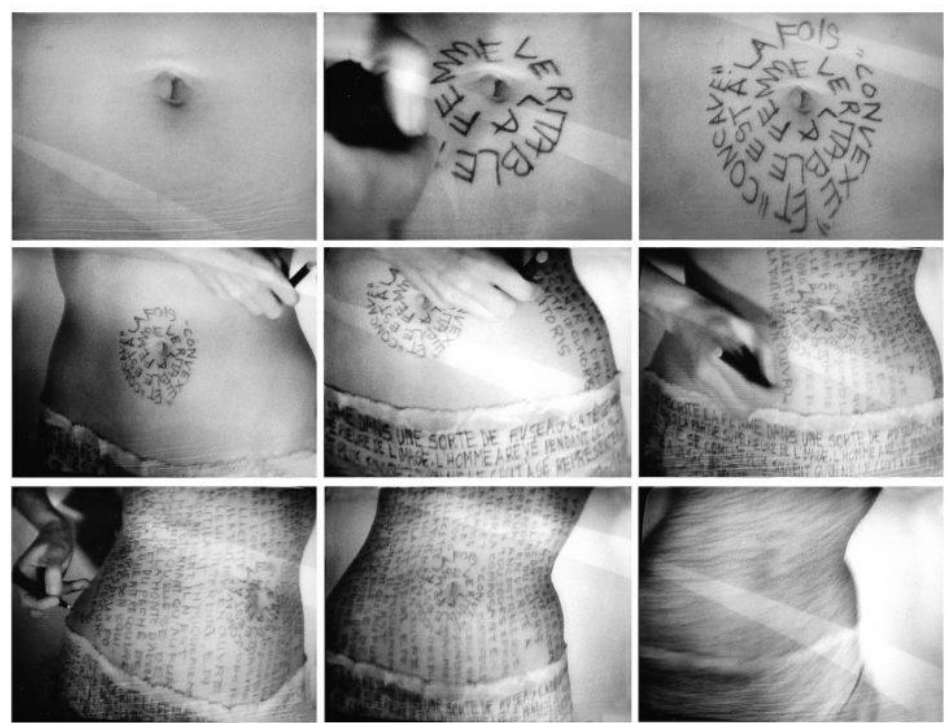

Görsel 4. Nil Yalter, Göbek Dansı Videosu, 1975. (Kaynak: https://art50.net/batililasma-surecindengunumuze-turkiyede-sanat/)

Performanslarında pasif bir rol üstlenerek, kimi zaman bedenini halka açık ve müdahalelere izin verdiği bir nesne olarak sunan Yugoslav sanatçı Marina Abromoviç; izleyiciyle olan etkileşimi bu yönde gerçekleştirerek sanatsal eylemlerinde rahatsızlık veren gösterilere imza atmıştır.

Abramoviç, performanslarında kendi bedeninin sınırlarını oldukça keskin bir biçimde zorlamaktadır. Kadın cinsiyeti bağlamında, dinsel bağlamda ve siyasal bağlamda, içinde yaşadığı toplumun marazlarını sorgulayan ve sorgulatan konuları performansları aracılığıyla görünür hale getirmektedir. Bedeni üzerindeki denetimini kendi eline alıp acıyı kendi uygulayarak, kimi zaman da bu işi izleyiciye vererek denetimin elini ve sorumluluğu değiştirir. Çağdaş toplumun ölüm korkusu ve acı üzerindeki algıyla hareket ederek, acıyı kendi bedeninde gerçekleştirerek bedeninde açtığ1 yaralarla tarihin toplumda açtığı yaralara göndermeler yapar. Sanatçı performanslarında kullanacağı her aleti, materyali belirli bir mantıki çerçeve içerisinde oluşturmuştur fakat yine de performansları bir çok performansta olduğu gibi rastlantısallığa açıtır. Ancak bu rastlantısallık izleyici açıcından açık mesajlara gebe, izleyicini zihninde alacağ1 yol konusunda açıktır. Başta Balkan savaşı olmak üzere tüm savaşları lanetlemek için gerçekleştirdiği balkan Broque performansında (Görsel 5), kanlı hayvan kemiklerini attığı ve gittikçe aha fazla 1sınmasıyla kokunun arttığı bodrum katında dört gün geçirmiştir. Performansı sırasında halk şarkıları söyleyerek yer yer 


\section{BEDENİN BİR DİRENISŞIN ESTETIGĞI OLARAK PERFORMANS SANATINA DÖNÜŞÜMÜ}

ağlayarak kemikler ve kanla bedenini bütünleştirerek herkesin yapamayacağı kadar ağır ama pasif bir direniş estetiğini bizlere yaşatmıştır.

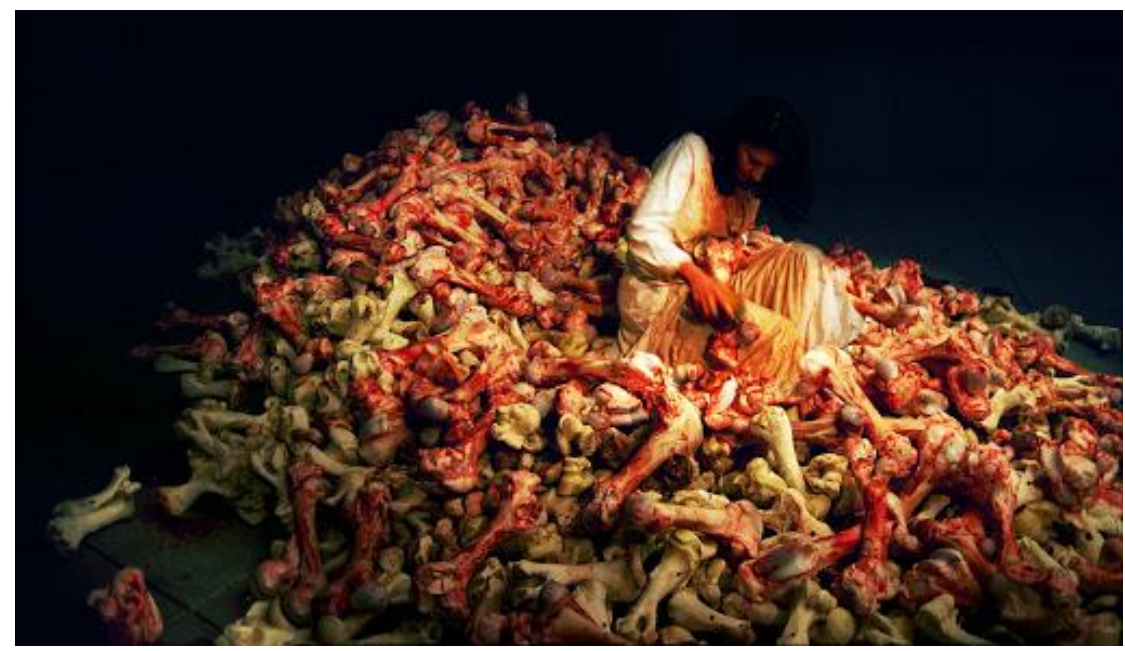

Görsel 5. Marina Abramoviç, “Balkan Broque”, 1997. (Kaynak: http://www.sanatatak.com/view/aninpatikasinda-yasayan-bir-zaman-gezgini-marina-abramovic)

1974 Rhytm 0 (Ritim 0) ismiyle gerçekleştirdiği performans (Görsel 6), izleyicinin şiddete olan eğilimi açığa çıkarması ve sanatçının kendisinin değil, izleyicinin sanatçıya uyguladığı şiddet açısından oldukça çarpıcıdır. Sanatçı masanın üzerine sıraladığı 72 objeyi, kendi bedeni üzerinde her türlü müdahaleye açı ve izleyicinin özgürlüğüne bırakmıştır. Bu objeler arasında, şarap, üzüm, makas, parfüm, metal çubuk, güller, ekmek, bir silah ve silaha uyan bir mermi de bulunmaktaydı. Altı saat süren performans normal bir şekilde başlarken yavaş yavaş akıllara durgunluk verecek bir biçimde devam etmeye başlamıştır. İzleyiciler sanatçının masaya bıraktığı jileti alarak sanatçının boynunu yaralamış, sanatçıyı kol ve bacaklarından tutup salonda gezdirmiş, sanatçıyı masaya bırakıp bacaklarının arasındaki boşluğa bıçağı saplamışlar, yetmediği gibi daha da ileri giderek masadaki tabanca mermiyle doldurulup sanatçıya doğrultulmuş. Vardar (2015)'ın ifade ettiği gibi; sanatçı , performans sürecinde tüm kontrolü izleyicinin eline bir oyuncak gibi bırakmış, galeri sahibinin müdahale ederek performansı bitirmesiyle kendisine gelmiştir. Aynı şekilde izleyici de, performansın bitiminde içine girdikleri o duygu durumundan çıkarak acı verdikleri o nesne bedeni, ilk halindeki kişiliği ile görmeye başlamışlardır.

Sanatçı hayati risk taşıyan ve gerçekleştirdiğinde de tehlikeli bir sınıra dayanan bu performansıyla izleyici tarafından ağır bir şiddete maruz kalmıştır. 


\section{BEDENİN BİR DİRENISŞIN ESTETIGĞI OLARAK PERFORMANS SANATINA DÖNÜŞÜMÜ}

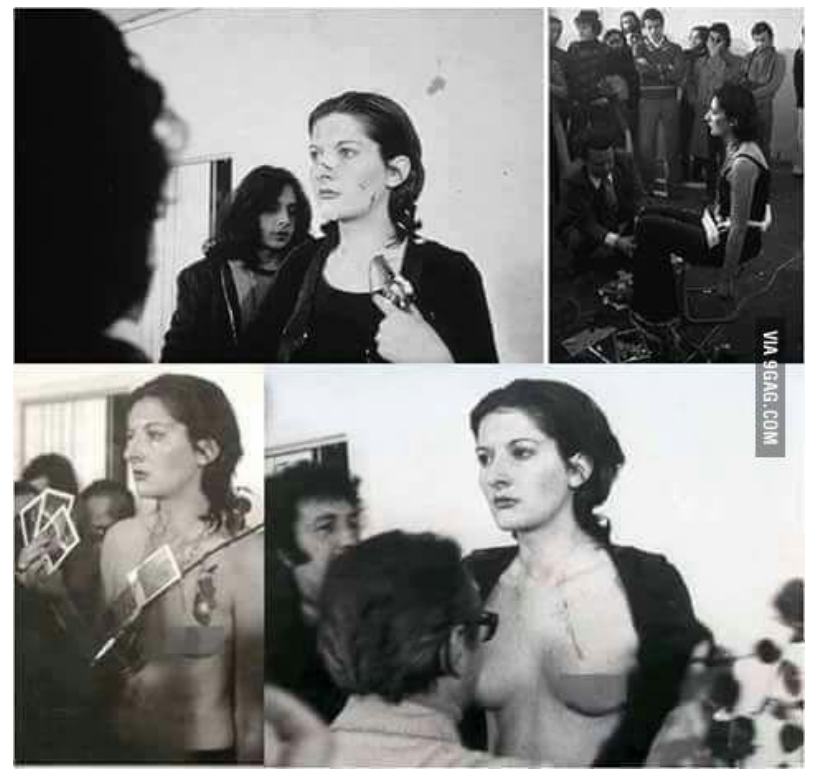

Görsel 6. Marina Abramovic, Rthym 0 (Ritim 0), 1974. (Kaynak: https:/ / seyler.eksisozluk.com/vucudununve-seyircinin-sinirlarini-gormek-isteyen-m-abramovicin-unutulmaz-performansi-rhythm-0)

Sanatçı performansından önce izleyiciler için galeriye yerleştirdiği "Ben bir nesneyim' yazılı not, öncelikle kendi dişiliği ve cinselliği arasındaki ilişkiyi sorgular. Aynı zamanda bir sanatsal nesneyi ya da eyleme dayanan bir işi seyretmek için eğitilmiş halkı, nesneliği gösteren kadınla yüzleştirir ve izleyenleri kendi davranışlarını izleyen seyirciler durumuna sokar" (K1lınç, 2007 : S.50).

Modern Batı toplumunun oluşturduğu güzellik algısı etrafında kadın bedeninin kuşatılmasına, bu algıyı şekillendiren ve yayan görsel medyaya karşı bedenine yaptırdığı çeşitli estetik operasyonlarla direniş sergileyen sanatçı Orlan'ın ameliyat performansları (Görsel 7), iktidarın tıp aracılığıyla beden üzerinde oluşturduğu tahakkümü akla getirir. Orlan;

tıpkı öznelliğimiz gibi, teknolojinin de bizim hayal ettiğimiz kadar saf olmadığını göstermek ister. Bu açıdan, tehlikeli bağlantılarıyla bedenlenmenin kimlikten önce var olduğunu göstermektedir. Onun bedenlenmesi, tehlike, tutku ve provokasyonu işaret eder; ki bu, görselliğin günahkar bir oyunu olarak cinselliğin ayrıcalığının ya da gündelik hayatın kültürel narsisizmine yönelik sorgulayıcı bir bakış açısının yansımasıdır (Şahiner, 2015: s.189).

Onun Carnal Art olarak nitelendirdiği ameliyat performanslarındaki önemli nokta süreçtir. Bu ameliyatları estetik ameliyatlarının asıl amacı olan daha genç, güzel görünmek için gerçekleştirmez sanatçı. Bedeni üzerindeki denetimi ele alıp, "güzellik kavramını yeniden yapılandırmak ve kendi tarzına uygun bir şekilde bu kavramı yeni baştan yaratmak için"(2) gerçekleştirir. 


\section{BEDENİN BİR DİRENISŞIN ESTETIGĞI OLARAK PERFORMANS SANATINA \\ DÖNÜŞÜMÜ}

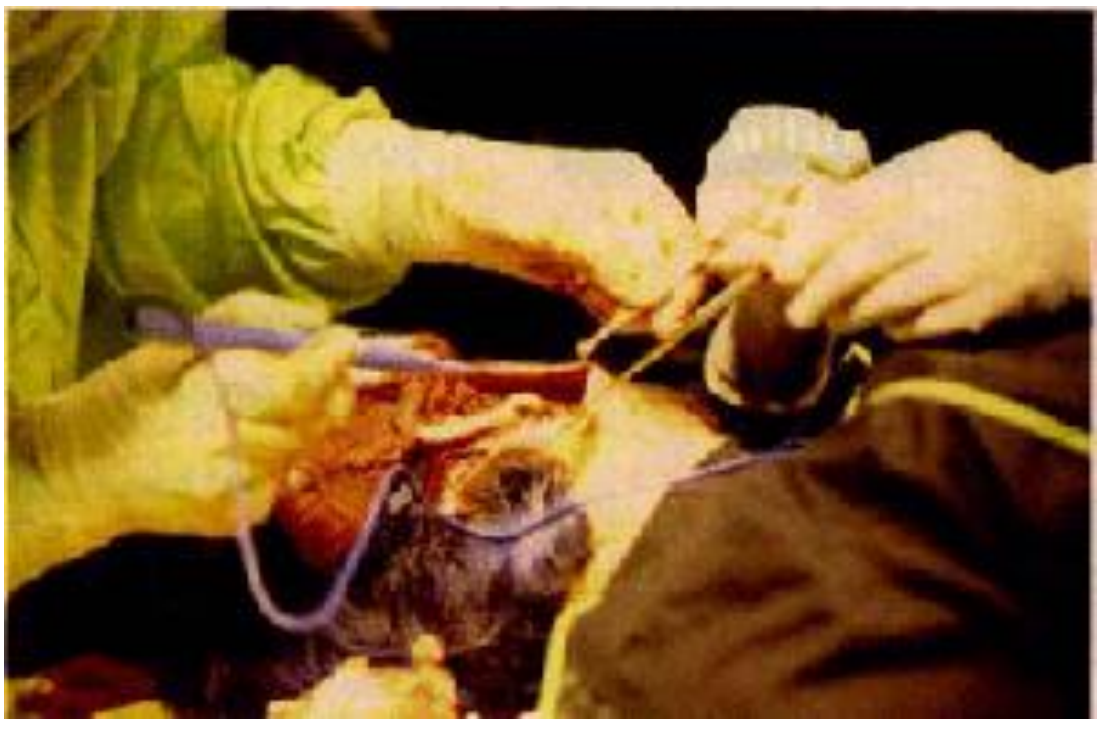

Görsel 7. Orlan, Ameliyat Performans, 1993 (Detay) (Kaynak: http://www.izinsizgosteri.net/asalsayi37/Kubilay.Akman_37.html)

Sanatçı ameliyatlarında lokal anesteziyi tercih eder. Ameliyatın verdiği acıyı deneyimlememek ve performans sonuna kadar izleyiciyle etkileşim halinde kalabilmek için böyle bir yol tercih etmektedir. Sanatçı kendi bedenini yeniden yapılandırırken tarihte güzelliği temsil eden beş kadının ayrı parçalarını alarak kendi yüzünde onları birleştirme fikri üzerine gider. Boucher'ın Europa'sının dudaklarını, Mona Lisa'nın alnını, Botticelli'nin Venüs'ünün çenesini, Gerard'ın Psych'sinin gözlerini, Diana'nın burnunu dijital bir ortamda birleştirir. $\mathrm{Bu}$ bağlam onun sanat tarihinin kadın temsillerine de gönderdiği bir eleştiri olarak düşünülebilinir.

Carnal Art manifestosunda Orlan, "ironik bir ifadeyle performe ettiği sanatın klasik anlamda, çağın mümkün kıldığı teknolojiyle gerçekleşen bir oto-portre olduğunu bildirir. Bu, çağımızın ulaşmayı henüz mümkün kıldığı, bedenin figürasyon ve disfigürasyonu arasında duran bir yazıttır. Orlan'a göre vücut 'değiştirilmiş bir hazır yapım' olmalıdır" (2) der. Acı, sanatçının performanslarını diğer performanslar arasında farklı bir noktaya taşıyan en ayırıcı özelliktir. Çünkü Orlan acıyı bir arınma amacı olarak kullanmaz. Hatta acıyı hiç kullanmaz ve performansları esnasında uyanıktır. İzleyici ile olan etkileşimde kitap okur, şarkı söyler. Onun performanslarında acı yoktur denilebilir. Performanslarını video aracılığıyla kalıcılaştırırken, bu videoları ameliyatından kalan et parçalarını, performanslarının ağır masraflarını karşılaşabilmek için kullanır.

Üretimlerini anti-konformist bir biçimde gerçekleştiren, yaşadığı çağın, toplumun patriarkal kültürel, politik marazlarına karşı direniş sergileyerek bedeni aracılığıyla sanatsal performanslar gerçekleştiren bir diğer sanatçı Şükran Moral'dir. Onun sanatsal 


\section{BEDENİN BİR DİRENISŞIN ESTETIGĞI OLARAK PERFORMANS SANATINA DÖNÜŞÜMÜ}

performanslarının teması genellikle savaşlar, genelevler, din ve toplumda marjinalleştirilenlerdir. Uluslararası düzeyde ses getiren üretimlerinden birisi 1994 yılında gerçekleştirdiği Artista (sanatçı) çalışmasıdır. İsa'nın Çarmıha Gerilmesi ikonografik sahnesini alaşağı ederek kendi bağlamı üzerinden tekrarlamıştır. Bir kadını üstelik kadın bir sanatçı İsa yerine çarmıha gerilmiş görünmektedir. Bu bağlamda kendisini İsa yerine koyan ilk kadın sanatçı olması açısından önemlidir ama bir o kadar da tepkileri üzerinde toplamıştır. 1997 yılında gerçekleştirdiği Bordolle (Genelev) performansında (Görsel 8) 27 saatini bir genelevde geçirir. Genelevin kapısına 'çağdaş sanat müzesi' yazmış, eline de 'satılık' (for sale) yazan bir kağıt almıştır. "Bu şekilde müze ve genelev arasında bir bağlantı kurmaktadır. Müze ve sanatçı kavramlarını genelev ve fahişe kavramları üzerinden eğretileme ile kullanmıştır. Bu yine incelikli bir sanat tarihi eleştirisidir. Çünkü, estetik bakış nesnesini deneyimler, onu tüketmez "(Arapoğlu, 2016: s.59).
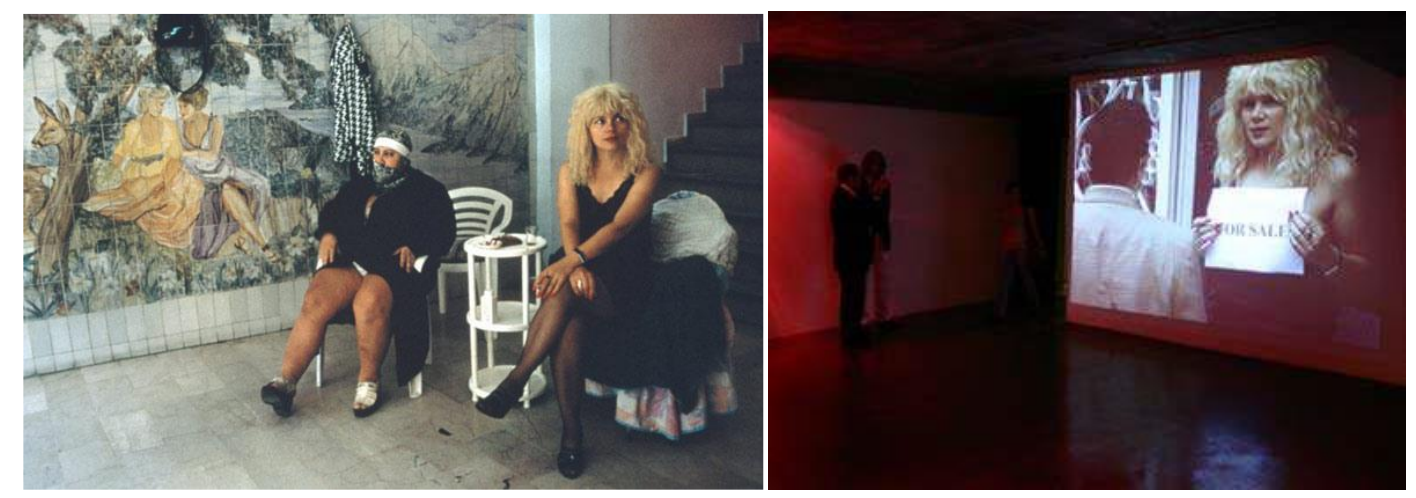

Görsel 8. Şükran Moral, Genelev 1997. (Kaynak: http://www.milliyetsanat.com/yazar-detay/ozgeyilmaz/sukran-moral-uzerine/1609)

Şükran Moral, müzelerin sanatçılara olan yaklaşımlarını eleştirilirken aynı zamanda toplumun kadınlara olan bakış açıları ve değer yargılarına direnen ve eleştiren bir performans gerçekleştirmiştir. Bu açıdan da güncelliğini koruyan; görünen o ki uzun bir sürede koruyacak olan bu performans ile ayn zamanda, kadın bedeninin metalaşmasının resmiyeti ile ataerkil toplumun objesi olarak devam eden rolü sorunsallaştırmıştır.

Hermann Nitsch "1962'de canlandırmaya başladı̆̆1 devam eden on yılda da gerçekleştirmeye devam ettiği kanlı ritüeller serisinde "kendi bedenini ekspresyonist bir biçimde kullandı. Freudcu psikolojinin yanı sıra aksiyon resminden de ilham alan sanatçı, korku aracılığıyla psikolojik katarsisin peşine düşmüştü. (...) Amaç sanatçının ve izleyicinin doğal fakat toplumsal olarak bastırılmış saldırgan içgüdülerini serbest bırakmaktı" (Fineberg, 2014. s.332). Performansları (Görsel 9) Şaman ayinlerine ve aktivitelerine benzese de izleyici açısından tiksindirici, algıda şok etkisi yaratan, sorgulayan ve sorgulatan içerisinde direniş ile tiksintiyi estetik bir noktada barındıran 


\section{BEDENİN BİR DİRENISŞIN ESTETIGĞI OLARAK PERFORMANS SANATINA \\ DÖNÜŞÜMÜ}

olgular taşır.

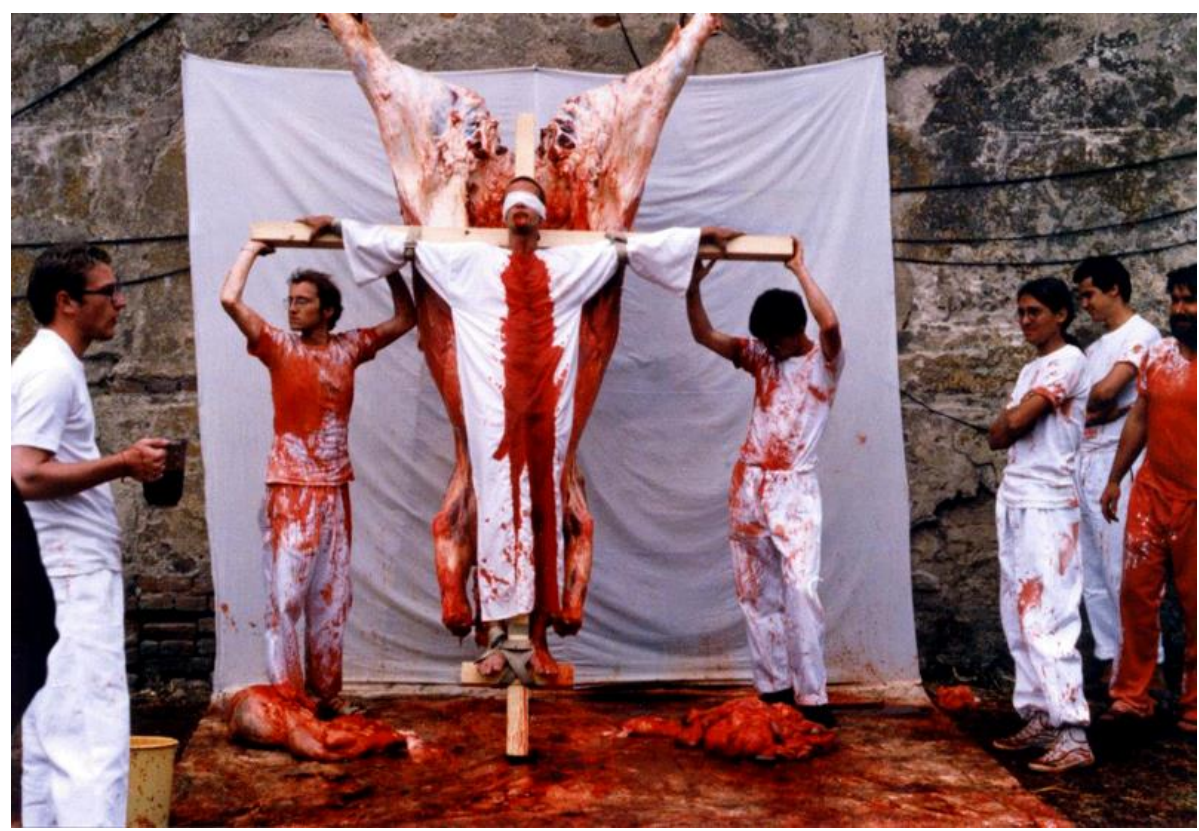

Görsel 9. Hermann Nitsch, Orgien Mysterien Theater (Gizemli Alem Tiyatrosu), 1998. (Kaynak: http://www.all-art.org/art_20th_century/nitsch1.html)

Sanatçı aynı zamanda 1965 yılında Viyana Aksiyonizmini oluşturmuştur. O üretimlerinde bedeni bütün biçimleriyle kutsar ama bunu yaparken onu bozarak, kurban ederek kimi zaman yaralayarak idealize edilmiş beden algısını yerinden oynatarak eleştirel bir bakış getirir. Onun performanslarında modernizmin kutsadığı sanatın evrensel ve değişmez kabul edilen estetik ve plastik ilkelerine karşı bir direniş ve başkaldırı mevcuttur. Müze ve galerilerden özerkliğini alan sanatın mekanı şimdi ve her yerde şekline bürünmüştür. Burjuvanın beyaz duvarlarında halktan uzak ve ayrıcalık kadehine doldurulan içecekleri yudumlayarak seyre dalınan sanat biçimleri, sokağa, yaşamın devam ettiği her mekanda, hayatın içerisine daha çok girerek yaşamın kendisine talip biçimde hareket etmektedir. Sanatın metalaşması ve ticarileşmesinin getirdiği yaratımsal sanrılara tepki olarak sanatın gerçek hayatın içine sokulmasıyla yaratmanın özgürlügünün deneyimleşmesinin yolu açılmıştır.

Regina Jose Galindo, Who Can Erase the Trace? (Bu izleri kim silecek?) (Görsel 9) isimli performansında Guatemala Anayasa Mahkemesi binasından eski Ulusal Saray'a kadar yürümüştür. Fakat yürümeden önce ayaklarını içinde insan kanı bulunan beyaz bir kaba aralıklı olarak sokarak kan ile boyanmasını sağlamıştır. Kanlı ayaklarının oluşturduğu izler ile birlikte yürüyüşünü gerçekleştirmiştir. 30 yıl süren bir iç savaşta, sivil halkın öldürülmesine bir tepki ve eleştiri olarak direnişini ortaya koymuştur. 


\section{BEDENİN BİR DİRENISŞIN ESTETIGĞI OLARAK PERFORMANS SANATINA \\ DÖNÜŞÜMÜ}
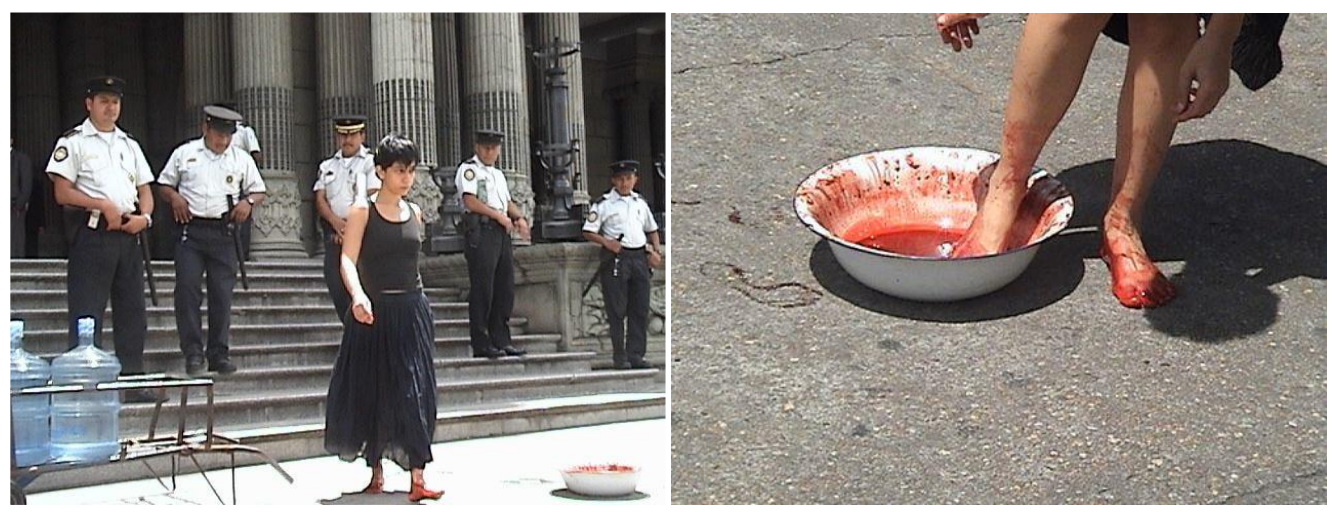

Görsel 9. Regina Jose Galindo, Who Can Erase the Traces 2003. (Kaynak: https://lareviewofbooks.org/article/amnesty-justice-art-regina-jose-galindo/)

\section{Sonuç}

Direnişin beden aracılığıyla sanatsal bir estetiğe dönüşmesinin incelendiği bu çalışma sanatın ve direnişin sonsuz biçimi ve dili olduğuna işaret etmektedir. Modernitenin ve onun kurumlarının gizli ya da açık bir biçimde uyguladığı denetim mekanizmalarına bir eleştiri niteliğinde olan bu çalışmada, postmodern performans sanatçılarının beden algıları ve beden üzerindeki tahakkümleri ele alınmıştır. Sanatsal ifadelerini beden üzerinden gerçekleştiren sanatçılar, özellikle kendi bedeni üzerindeki denetimi ele alarak, çeşitli iktidar mekanizmalarının beden, cinsiyet, ırk politikalarını görünür kılınarak, eleştirme ve gösterme bağlamında bu mekanizmalara bir direniş sergilenmiştir. Aynı zamanda sanat tüketimini yeniden gözden geçirip, sanatın tüketimine demokratik bir şekilde yaklaşarak, her yerde herkesle sanat performansları gerçekleştirerek kapitalizme karşı da bir direniş estetiği gerçekleştirmişlerdir. Sanatsal performansları aracılığıyla, sanatla hayatı birleştirerek izleyicinin pasif alıcı konumundan çıkarıp, sanat üretimiyle etkileşime girip, sürece dahil ederek sanat eyleminin ve üretiminin elitist yaklaşımı sorgulanarak tersine çevrilmiştir. Bu açıdan performans sanatının, sanatın yaratıcılık dilini şu anda öngöremeyeceğimiz noktalara taşıyacak potansiyelinin olduğunu ve sanatın tek işlevinin temsil etmek değil direnmenin de sanat olabileceğini bedenin bir direnişin estetiği olarak performans sanatına dönüşümüyle görmüş olmaktayız.

\section{KAYNAKÇA}

Akçay, A.(2004). Beden, Felsefe Ansiklopedisi, ed. Ahmet Cevizci, ss. 231-237, İstanbul: Etik Yayınları.

Akkol, N.(2018). Acıyı Deneyimleme: Gina Pane Performansları, İdil Dil ve Sanat Dergisi, C.7, S.50. 


\section{BEDENİN BİR DİRENISŞIN ESTETIGĞI OLARAK PERFORMANS SANATINA \\ DÖNÜŞÜMÜ}

Antmen, A.(2008). 20.Yüzyıl Batı Sanatında Akımlar, İstanbul: Sel Yayıncllı.

Arapoğlu, F.(2016). Şükran Moral Özelinde Türkiye'de Feminist Sanatta Kimlik ve Farklılık, Tykhe Sanat ve Tasarm Dergisi, C.1S.1 (52-63).

Bingöl, O., (2019). Foucault'da İktidar, Beden ve Özne Üçlüsü, Asia Minor Studies, Cilt 7 Sayı 2, 327-334,

Fineberg, J. (2014). 1940'tan Günümüze Sanat: Varlık Stratejileri, (Çev. Simber Atay-Eskier ve Göral Erinç Yılmaz, İzmir: Karakalem Kitabevi Yayınları

Işık, E. (1998). Beden ve Toplum Kuramı. Bağlam Yayınları: İstanbul

Kılınc, G.M.(2007) Bedenin İktidar kavramına Karşıt Bir Öğe Olarak Vücut ve Performans Sanatı'nda Kullanılması, Mustafa Kemal Üniversitesi Sosyal Bilimler Enstitüsü)

Özbay Aydoğan S. M., (2006). Kadın Bedeni Kurguları ve Temsiliyet: 1970 Sonrası Batı Sanatıda Bedenlerini Kullanan Kadın Sanatçları, (Yayınlanmamış Yüksek Lisans Tezi). İstanbul: Yıldız Teknik Üniversitesi Sosyal Bilimler Enstitüsü.

Şahiner, R. (2015). Çağdaş Sanatta Temsiliyet Krizi: Çă̆daş Kuramlar ve Güncel Tartışmalar, Ankara: Ütopya Yayınları

Tezkan, M. (2009). Gerçekliğe Alternatif Bir Gerçeklik: Nil Yalter Videosu. Erişim, 1, 2016.

Vardar, B. (2015) Bir Güncel Sanat Pratiği Olarak Beden Performans Sanatı ve İtalyan Performans Sanatçıları, (Basılmamış Yüksek Lisans Tezi), İzmir: Yaşar Üniversitesi Sosyal Bilimler Enstitüsü

Yilmaz, M. (2006). Modernizmden postmodernizme sanat. Ütopya.

https://medium.com/@ecebasar/\%C3\%B6nc\%C3\%BC-feminist-sanat\%C3\%A7\%C4\%B1-caroleeschneemann\%C4\%B1n-ard\%C4\%B1ndan-124993269211

http://www.izinsizgosteri.net/asalsayi37/Kubilay.Akman_37.html 